Journal of Balkumari College

ISSN 2467-9321 (Print), ISSN 2738 -957X (Online) Website: http://balkumaricollege.edu.np/journal

Volume : 10 Issue: 1 June 2021, Page No. 13-18

\title{
Impact of Training \& Development and Career Planning on Employee Involvement
}

\author{
Dr. Gopal Man Pradhan \\ Associate Professor, Bhaktapur Multiple Campus, Bhaktapur \\ mrprakashshrestha@gmail.com \\ Dr. Prakash Shrestha \\ Lecturer, Nepal Commerce Campus, Kathmandu \\ mrprakashshrestha@gmail.com
}

\begin{abstract}
The purpose of this research is to investigate the impact of training and development as well as career planning in Nepalese service sector organizations. Data for this study were gathered from service organizations such as banks, insurance companies, telecommunications companies, hospitals, and colleges. In total, 502 questionnaires were distributed, and 82.97 percent of the copies that were filled out and returned were used in the study. Descriptive statistics, correlation, and multiple regression were used to analyze the data. Organizational training and development and career planning, according to the study's findings, have a significant impact on employee involvement in their jobs and performance. As a result, Nepalese service sector organizations must make provisions of the budget for additional employee training and development programs. Similarly, it is necessary to provide employees with career development opportunities so that they can stay with the company for an extended period.
\end{abstract}

Keywords: Training and development, Career planning, Employee involvement, Service sector, Human resource management

\section{Introduction}

Training and development, career planning, and employee involvement are the essential components of human resource management of the organization for its effective functioning and to achieve predetermined objectives. The objective of the organization is not only to select the right persons for the right job but also to encourage them for the best use of their efficiency and effort for better performance of the organization. Human resource is said to be the dynamic resource and the successful functioning of the organization is depends on the attitude, behavior, and performance of the employees. Armstrong (2012) argues that human resource management is organized, a key way to achieve, create, monitor and motivate and gain worker dedication. Human resource practices are critical to administrative development (Hallberg \& Schaufeli, 2006). There are some practices done by the human resource are recruitment, selection, preparation, employee performance improvement, planning strategy, and evaluation (Tessema \& Soeters, 2006). Therefore, effective training and career development information must be provided for these unique assets to maximize professional commitment. In addition, they can cope with the challenges of today's competitive business environment. Despite extensive research in the field of human research management, training for staff, especially in developing countries, is not satisfactory. Today, employee involvement is very significant for the effective use of organizational resources consisting of material, machines, and equipment, money, and technology. Sims (2012) suggested that employee involvement can ultimately show how powerful human resource management practices can be more effective in implementing individuals and businesses. The organizational goal is to improve its performance, but without the effective performance of its employees, this will never be possible. As a result, the performance management system has become a management transformation to discourse and accurate organizational concerns.

Engagement is characterized as an employee's emotional attachment to their organization and its goals. "Engage or die" has become a key phrase in the lexicon of organizational behavior (Semwal \& Dhyani, 2017). Organizations value employee engagement because it is directly related to high employee performance and organizational performance. Employees who are engaged care about their company and strive to make it a success. Training and development are critical components in keeping an employee engaged and productive in the workplace. Employees may become dissatisfied if they want to advance in their careers but are unable to do so. Employee engagement is the most researched topic in organizational science (Carasco-Saul, Kim, \& Kim, 2015), with research linking engagement to both career development (Simon, 2012) and career-development opportunities 
(Bakker \& Demerouti, 2007). Career development is an excellent way to engage employees while also recognizing, motivating, and retaining them. The best way for managers to begin career development plans with employees is to meet with them individually and learn about their talents, areas for improvement, and long-term career goals. That is why organizations must invest in career development in order to retain employees and reduce turnover. A feeling of psychological connection with the organization emerging out of a pleasurable or positive emotional state leading to job satisfaction, commitment, sense of pride towards the organization, wanting to stay with the organization, forming emotional connect and recommending others also to work with the organization (Lather \& Jain, 2015).

\section{Statement of Problems and Research Questions}

The impact of training and development, as well as career planning, on employee involvement, is regarded as one of the most universal methods of improving an organization's employee productivity and performance levels. It is also a crucial administrative function in human resource management (HRM). Given the enormous importance of training and development for the benefit of employees and, by extension, organizations, the United States spent 164.2 billion dollars on training and development programs in 2016 (Sitzmann, 2018). Employees are hired in every organization based on their skills, efficiency, and knowledge, and they typically receive various types of benefits such as wages, salaries, bonuses, commissions, and so on. They must, however, participate in training and development programs to improve their job-related efficiency and skills in order to effectively solve job-related issues and problems. Furthermore, most career-oriented employees with good and solid educational backgrounds are unmotivated to do their best on the job when they do not get a job that is supportive of future career development. Many scholars have discovered a lack of proper training and development, as well as career development programs, in many developing-country business organizations, including Nepalese business organizations (Adhikari \& Gautam, 2006). Based on these discussions, the following questions may arise in the research:

- What is the situation of training and development, and career planning in service sector organizations in Nepal?

- What is the impact of training and development on employee involvement in service sector organizations in Nepal?

- What is the impact of career planning on employee involvement in service sector organizations in Nepal?

\section{Research Objectives}

The main objective of this research study is to assess the training and development, and career planning system in service sector organizations of Nepal and know their impact on employee involvement for the accomplishment of assigned effectively. However, the following are the specific study of this research work.

- To investigate the situation of training and development and career planning in Nepalese service sector organizations;

- To examine the impact of training and development on employee involvement in Nepalese service sector organizations; and

- To examine the impact of career planning on employee commitment in Nepalese service sector organizations.

\section{Literature Review}

Many types of research are conducted across national and international levels to map employee involvement and to understand its linkages with other factors consisting of employee training and development and career planning. In the present competitive business world, the most crucial asset possessed by organizations is their employees and their attitude, behavior, and performance. They are considered as the intellectual capital of the organization and their creativity must be used for obtaining competitive strengths of the organization. Khan et al. (2016) construed that training and development, career planning, and employee involvement are important parameters of employee performance. In their study, they attempted to study the effect of training and development on the performance of the employee through involvement and job satisfaction. The results revealed that there is a positive impact of training and development, and career planning on employee involvement and their performance. Thus they concluded that investing in training and development programs and providing career development opportunities among the employees will increase their job satisfaction and involvement in assigned jobs. 
Organizations which invest in their employee's development are likely to have better-engaged employees (Pradhan, 2019). The impact of Training and Development practices and career development on overall employees' engagement are interrelated along with different factors of employee involvement. These factors are job satisfaction, organizational commitment, advocacy, pride, intention to stay, and emotional connect (Jain \& Khurana, 2017). Training and development, career planning, and other factors have a significant impact on the commitment and involvement of the employees, their performance, and retention (Nkosi, 2015). There is a significant difference amongst the engaged and disengaged employees concerning employees who underwent training and those employees who didn't undergo any training to enhance the work efficiency. Results show that Employee engagement has a positive correlation with the performance of the employee, the safety of the officers, and their retention (Arunmozhi, 2015). Bersin (2015) in its refreshed model of engagement also highlighted training and development as a growth opportunity that supports in improving the employee engagement in the organization apart from other factors like meaningful work, hands-on management, a positive work environment, and trust in leadership. Gamage and Imbulana (2013) researched to study the impact of training and development, career development on the performance of the employees. The study concluded that training and development, and career planning of employees have a significant positive relationship with the productivity of the employee and job satisfaction. Irmer and Jorgensen (2009) in their model of employee involvement proposed that learning and development, career planning, reward and recognition, job design, leadership, and work environment are key drivers to the emotional involvement of employees in their performance.

\section{Research Methodology}

\section{Framework of the Study}

The major focus of this study is on-the-job and off-the-job dimensions of training and development programs and similarly, career planning involves career counseling and mentoring roles played by the managers in the organization. The employee involvement may be represented validation, recognition, and feedback of employees' performance. Based on the study of various literature, the research framework is presented as follows:

Figure 1. Framework of the Study

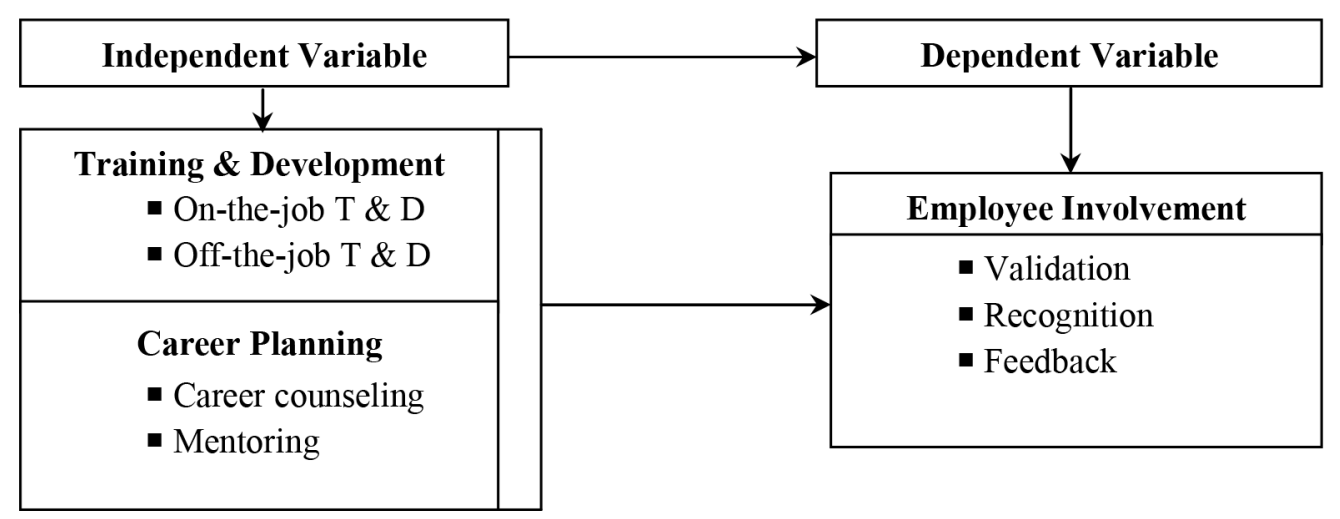

Training and development programs are designed for mutual benefit (employees and the organization), which contributes to high effectiveness (Noe, 1986). Improving employee performance is a demanding and ongoing practice that allows organizations to compete in a competitive marketplace. It is possible if employees' attitudes, knowledge, and skills are regularly developed. Despite the fact that training is an expensive activity, it can provide numerous benefits such as improved employee performance, increased productivity, and employee development (Elangovan \& Karakowsky, 1999). Training and development programs may be on-the-job or offthe-job, depending on the organization's needs and requirements.

Career planning is a continuous process in which an individual establishes career goals and determines how to achieve them. Essentially, two components of career planning play major roles in the organization, which are career counseling and mentoring. Career counseling is a process that assists individuals in getting to know and understand themselves as well as the scope of their work in order to make career, educational, and life decisions. Mentoring is a relationship between an elder and a junior in which the elder guides the younger person through difficult times and provides advice and support. It promotes information sharing across the organization and helps new employees understand the organizational culture. 
Employee involvement is founded on three pillars: validation, recognition, and feedback. Validation is the unconditional recognition of an employee's intrinsic human value, regardless of performance, and includes listening, caring, and responding from the heart. Great managers make validation a daily habit by inquiring about their employees' health, children, and weekend plans. They recall family members' names as well as significant events in their lives. The term "recognition" refers to conditional praise given in exchange for job performance, behavior, and attitude. It is the foundation of a high-performance culture because it is a positive expression of appreciation for a job well done and expectations met. Feedback refers to periodic, confidential conversations about performance, behavior, and attitude that are intended to foster an employee's personal growth and improvement by providing critical and supportive insight into how their manager and other company stakeholders view their work.

\section{Research Design}

This study is based on primary data collected from a random sample of respondents via the distribution of questionnaires. As a result, the research is a descriptive, correlational, and causal comparison in nature. In order to obtain feedback from both managerial and subordinate level employees of selected Nepalese service organizations, this study took into account some selected training and development and career planning-related variables. The research design adopted in this is identical to the previous researches taken place, for example (Armstrong, 2012, Guest, 2002) showing the effect of training and development, career planning on employee involvement on the job.

\section{Research Hypothesis}

The broad objectives of this study are to explore the impact of training and development, and career planning on employee involvement of Nepalese service sector organizations. Based on the above objectives and relation, the following hypotheses are explored:

Hypothesis 1: There is a positive and significant effect of training and development on employee involvement.

Hypothesis 2: There is a positive and significant relation and effect of career planning on employee involvement.

\section{Sources and nature of data}

Data for this study were gathered from service organizations such as banks, insurance companies, telecommunications companies, hospitals, and colleges. In total, 502 questionnaires were distributed, and 82.97 percent of the copies that were filled out and returned were used in the study. The questionnaire was developed by considering the prior literature as used by Guest (2002). Normative theory of maintaining the link between training and development, career planning, and employee involvement was taken into account in this research work.

\section{Empirical Data and Results}

In this regression model employee involvement is considered as dependent variable $Y$ and two variables consisting of training and development and career planning are considered as independent variables. The following multiple regression table shows the effect of two variables on employee involvement:

Table 1. Effect of training and development and career planning on employee involvement

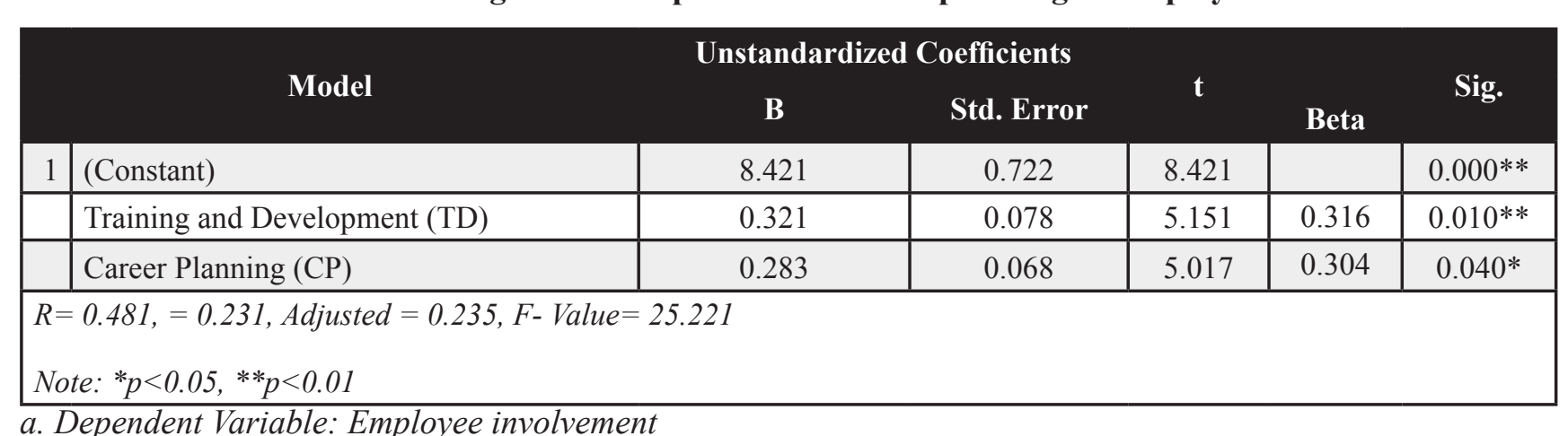

a. Dependent Variable: Employee involvement

$$
\begin{aligned}
\mathrm{Y} & =\mathrm{a}+\mathrm{b}_{1} \mathrm{TD}+\mathrm{b}_{2} \mathrm{CP}+\mathrm{e} \\
& =8.421+0.321 \mathrm{TD}+0.283 \mathrm{CP}+\mathrm{e}
\end{aligned}
$$




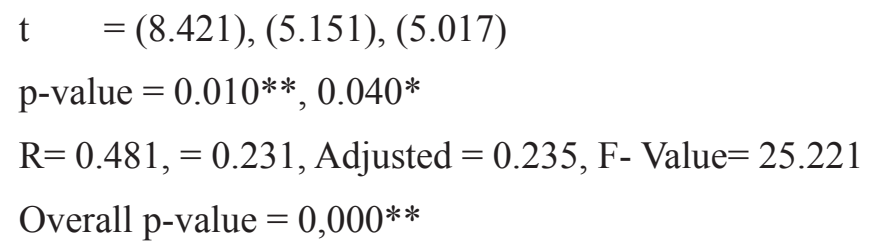

The $\mathrm{R}^{2}$ is 0.231 . It means that only $23.1 \%$ of the total variation is explained by this model and another part of the explanation is made by other variables which are not included in this study. The F-value is 25.221 and the overall $\mathrm{p}$-value is 0.000 . Thus, the multiple regression model used in this study is fit and appropriate because the ANOVA table shows that the F- value is significant at a $5 \%$ level of significance.

The calculated p-values of training and development and career planning 0.010 and 0.040 respectfully which are significant at a $5 \%$ level of significance. Therefore, both two variables are predictors of employee involvement. While analyzing the beta coefficient, single variable training and development to employee involvement is high (0.316) followed by career planning (0.304) therefore both variables have a positive impact on employee involvement. Hence, both the hypotheses were supported. However, training and development have more impact on employee involvement as compare to career planning developed by the organizations.

\section{Discussion and Conclusion}

The purpose of this research was to investigate the impact of training and development as well as career planning in Nepalese service sector organizations as identified by Pfeffer (1994) and Guest (2002). The results show that the beta coefficient, variable training and development's sensitivity to employee involvement is high followed by career planning. Thus these two variables are considered as a valuable and significant predictor of employee involvement in the organization for accomplishment of assigned jobs. In conclusion, the research found that two variables consisting of training and development and career planning have a positive impact on employee involvement in service sector organizations. According to Guest (2002), the following practices are related to employee involvement: training and development. Employee involvement is explained by the regression coefficients of training and development and career planning, which both positively contribute to organizational performance. These findings are consistent with the studies of Jiang and Men (2015); Kang and Sung (2017), Manuel (2014); Mishra, Boynton \& Mishra, (2014). This may imply that Nepalese service sector organizations must invest additional funds to enroll employees in training and development programs in order to improve job performance. This may imply that Nepalese service sector organizations must invest additional funds to enroll employees in training and development programs in order to improve job performance. Furthermore, it is critical to provide employees with career development opportunities within the organization so that they can stay with the organization for a long time and contribute their best to improving the organization's performance outcomes.

\section{REFERENCES}

Adhikari, D.R. \& Gautam, D.K. (2006). Human resource management in Nepal: integration and organizational performance, Banijya Sansar, 12, 31-37.

Afroz, N. N. (2018). Effects of training on employee performance - A study on banking sector, Tangail Bangladesh. Global Journal of Economics and Business, 4(1), 111-124.

Armstrong, M. (2012). A handbook of human resource management practice (9th ed.). Kogan Page, London.

Arunmozhi, T. (2015). A study on employee engagement and involvement practices In ICICI Bank Ltd., Chennai. Indian Journal of Applied Research, 3(4), 76-78.

Bakker, A. B., \& Demerouti, E. (2007). The job demands-resources model: State of the art. Journal of Managerial Psychology, 22, 309-328.

Bersin, J. (2015). Becoming Irresistible-A new model for employee engagement, Deloitte Review, 16, 146-163.

Carasco-Saul, M., Kim, W., \& Kim, T. (2015). Leadership and employee engagement: Proposing research agendas through a review of literature. Human Resource Development Review, 14, 38-63.

Elangovan, A. R. \& L. Karakowsky, (1999). The role of trainee and environmental factors in transfer of training: an exploratory framework, Leadership and Organization Development Journal, 20, 268-275.

Gamage, P. N., \& Imbulana, M. L. (2013). Training and development and performance of employees: Evidence from Sri Lanka Telecom. International Journal of Marketing, Financial Services and Management 
Research, 2(9), 12-24.

Guest, D. (2002). Human resource management, corporate performance and employee wellbeing: Building the worker into HRM. The Journal of Industrial Relations, 44(3), 335-358.

Hallberg, U. E., \& W. B. Schaufeli (2006). "Same Same" but different? Can work engagement be discriminated from job involvement and organizational commitment? European Psychologist, 11, 119-127.

Irmer, B.E., \& Jorgenson, C. (2009). Employee engagement drivers. Retrieved from: http://www.dynamiccapability. com.au/employee-engagement.htm

Jain, S., \& Khurana, N. (2017), Enhancing employee engagement through training and development, Article in Asian Journal of Management, 8(1), 1-6.

Jiang, H., \& Men, L. R. (2015). Creating an engaged workforce: the impact of authentic leadership, transparent organizational communication, and work-life enrichment, Communication Research, 44(2), 225-243.

Kang, M., \& Sung, M. (2017). How symmetrical employee communication leads to employee engagement and positive employee communication behaviors: The mediation of employee organization relationships. Journal of Communication Management, 21(1), 82-102

Khan, A. A., Abbasi, S. O., Waseem, R. M., Ayaz, M., and Ijaz, M. (2016). Impact of training and development of employees on employee performance through job satisfaction: A study of telecom sector of Pakistan. Business Management and Strategy, 7(1), 29-46.

Lather, A. S., \& Jain, V.K. (2015). Developing a scale to measure employee engagement. Dias Technology Review, 11(2), Available at SSRN: https://ssrn.com/abstract=3821368

Manuel, F. D. (2014). the effect of training and development on perceived business performance. Gordon Institute of Business Science, University of Pretoria.

Mishra, A., Boynton, L., \& Mishra, K. (2014). Driving employee engagement: The expanded role of internal communication. International Journal of Business Communication, 51(2), 183-202.

Nkosi, S. M. (2015). Effects of training on employee commitment, retention and performance: A case study of a local municipality in South Africa. European Journal of Business and Management, 7(15), 104-108.

Noe, R.A. (1986). Trainee's attributes and attitudes: Neglected influence on training effectiveness, Academy of Management Review, 11(4), 736-749.

Pfeffer, J. (1994). Competitive advantage through people: unleashing the power of the workforce, Boston; Harvard Business School Press

Pradhan, G.M. (2019). Human resource management practices and organizational performance in service sector organizations of Nepal. Unpublished Ph.D. Dissertation, Faculty of Management, Tribhuvan University, Nepal.

Semwal, M., \& Dhyani, A. (2017). Impact of employees training and career development on their engagement: A study using OCM and UWES measurement scales. NICE Journal of Business, 12(1), 85-101.

Simon, L. A. (2012). The influence of job, team and organizational level resources on employee well-being, engagement, commitment and extra-role performance; International Journal of Manpower, 33(7), 840853.

Sims, R. (2012). Organizational success through effective human resources management. Westport CT: Quorum Books.

Sitzmann, T. (2018). Training engagement theory: A multilevel perspective on the effectiveness of work-related training. Journal of Management, 20(10), 1-25.

Tessema, M. T., \& Soeters J. L. (2006). Challenges and prospects of HRM in developing countries: Testing the HRM-performance link in the Eritrean civil service. The International Journal of Human Resource Management, 17(1), 86-105.

Wiley, J. W., Kowske, B. J., \& Herman, A. E. (2010). Developing and validating a global model of employee engagement, in Albrecht, S.L. (Ed.), Handbook of Employee Engagement: Perspectives, Issues, Research and Practice, Edward Elgar, Cheltenham. 